Gut, 1961, 2, 12

\title{
Islet tumours of the pancreas with intractable diarrhoea
}

\author{
M. TELLING AND F. G. SMIDDY \\ From the General Infirmary at Leeds
}

SYNOPSIS This paper reports the association between severe, prolonged, watery diarrhoea and islet cell tumours of the pancreas. There appear to be significant differences between patients with these symptoms and those with the classical Zollinger-Ellison syndrome.

The association of non-insulin-secreting islet cell tumours of the pancreas with intractable peptic ulceration has been well documented by Zollinger and Ellison (1955) and by Ellison (1956). In their first communication (1955) they reported two such patients, both of whom presented with chronic ulceration of the jejunum. In each patient various surgical procedures, normally judged sufficient to control peptic ulceration, failed to prevent early recurrence. Necropsy in the first revealed a pancreatic islet cell tumour, whereas in the second, at a fifth abdominal exploration for recurrent gastrointestinal ulceration, routine inspection of the abdominal viscera disclosed two nodules in the pancreas; histological examination showed them to be composed of cells other than the B type. In neither patient was there evidence of hyperinsulinism, though in one a glucose tolerance test showed a slight defect.

Since 1955 many more examples of the ZollingerEllison syndrome have been reported (Summerskill, 1959; Pender, 1959; Rawson, England, Gillam, French, and Stammers, 1960). Indeed, by 1959 Zollinger and Elliott had collected a total series of 75 patients. The main features of this syndrome are intractable peptic ulceration of the stomach, duodenum, or jejunum, rapid recurrence of ulceration after apparently adequate surgery, a high level of gastric secretion, hypertrophic gastritis, and a non-insulin-secreting islet cell tumour of the pancreas, more commonly malignant than benign. More recently steatorrhoea has been noted (Summerskill, 1959; Maynard and Point, 1958; Rawson et al., 1960).

The first patient described by Zollinger and Ellison also complained of intractable diarrhoea which had begun eight years before the diagnosis of peptic ulceration; the absence of pathogens in the stools, together with the failure of oral antibiotics to control the diarrhoea, lead to an erroneous diagnosis of spastic colitis. Unfortunately this case report does not comment on the further course of the diarrhoea throughout the remaining two years of life which followed the diagnosis of jejunal ulceration; in fact little attention seems to have been paid to this diarrhoea at any point, although it was the patient's main disability. Forty and Barrett (1952) had previously described a patient with multiple islet cell tumours of the pancreas in whom persistent diarrhoea developed one year before peptic ulceration. Priest and Alexander (1957) reported a patient who, four years before coming under their care, had had a tumour of the body and tail of the pancreas removed. She remained well after this until jaundice developed for which cholecystectomy was performed. In the following year she developed watery diarrhoea; at necropsy several months later an islet cell tumour of the pancreas was found. In this patient there was no history or evidence of peptic ulceration until she was treated by cortisone, after which she developed melaena. Verner and Morrison (1958) described two more patients in whom severe intractable diarrhoea had developed; in each an islet cell tumour of the pancreas was found at necropsy, but in neither was there evidence of associated gastrointestinal ulceration.

In this article a further example of intractable diarrhoea (the daily stool volume being accurately known) associated with a non-insulin-secreting pancreatic tumour is recorded, and the literature is reviewed. We suggest either that peptic ulceration is not necessarily part of the Zollinger-Ellison syndrome, which in any case must be enlarged to include diarrhoea and steatorrhoea, or that the association of intractable diarrhoea, hypokalaemia, hyponatraemia, and islet cell tumours of the pancreas (excluding those arising in the insulin-secreting B cells), constitutes a syndrome entirely distinct from that described by Zollinger and Ellison. 


\section{CASE REPORT}

On 13 March 1958 a married Jewess, aged 55, was referred with a history of loss of weight, thirst, and frequency of 28 days' duration, and of pruritus vulvae for 10 days. Examination revealed only glycosuria, marked anxiety, and loss of weight. A glucose tolerance test on 18 March confirmed the diagnosis of diabetes mellitus, the blood sugar values being $130 \mathrm{mg}$. $\%$ fasting, and $260,340,330$, and $260 \mathrm{mg} . \%$ respectively. Sugar was present in all urines except the fasting specimen; ketone bodies were absent. Early admission was arranged, but the patient defaulted.

Her previous history was of good general health. In 1940 a right simple mastectomy had been carried out for recurrent abscesses (she was childless). In August 1957 she was very thoroughly investigated by Professor L. N. Pyrah for what appeared to be a left pyelitis with frequency, brief haematuria, and some dysuria. Culture of the urine, cystoscopy, and intravenous pyelography were all negative in September: she was given symptomatic treatment, including a course of oxytetracyclin, and her symptoms disappeared. These three examinations were repeated in December 1957, again with negative findings. During the last four months of 1957 she had had recurrent attacks of diarrhoea, with intervals of complete freedom. The motions varied from three to five a day, and were said to be loose and creamy. The diarrhoea seemed to have begun when she was receiving oxytetracyclin, and she received independent treatment for spastic colon.

She was seen again by M.T. on 16 September 1958, this time urgently at her home for gross diarrhoea and loss of weight. It transpired that after she had refused admission for stabilization of her diabetes, diarrhoea returned sharply, and she had seen another consultant who admitted her to hospital. Radiological investigation by barium meal and enema was negative, and the diabetes was said to have been controlled by a Lawrence diet of 12 black and nine red lines. She continued, however, to lose weight, and the diarrhoea soon returned. In June 1958, she sought the advice of a consultant in London, and was in hospital for seven weeks, returning home at the end of August. A barium meal and enema were repeated with negative findings, the diabetes was stabilized by diet and 20 units of Lente insulin daily, and she gained 2 stones in weight. The replacement of Lente insulin by Tolbutamide was followed rapidly by a return of diarrhoea, and she was mildly diarrhoeic at the time of discharge. The alkaline phosphatase was noted to be 67 units. Immediately after her return to Leeds at the end of August, diarrhoea became much worse, and when she was seen at home on 16 September, she was dehydrated, grossly emaciated, and unable to control the almost continuous passage of watery stools into her bed. Her blood pressure was $120 / 80 \mathrm{~mm}$. $\mathrm{Hg}$, the abdomen flatulent and distended, but examination was otherwise unremarkable. She was admitted to the General Infirmary at Leeds on 17 September.

SUBSEQUENT CLINICAL PROGRESS This may be summed up as a continuous metabolic battle, characterized by slow but relentless clinical deterioration, persistent hypokalaemia and hyponatraemia, ending by death on 16 December in electrolytic chaos, and high-lighted throughout by the passage of fantastically large, featureless, watery fluid stools, the daily totals regularly exceeding 4 and 5 litres, and on three occasions 6 litres, the highest being $6,900 \mathrm{ml}$. Permission for necropsy was refused.

Clinically the main features were steady decline and loss of weight, frequent vomiting, and inexorable dehydration. She was always afebrile, and her pulse rate ran between 72 and 96 . No abnormality was ever found in the abdomen, though it was at times 'doughy'. All other systems were always normal. Repeated blood counts showed only haemoconcentration in the early stages, typical findings being, R.B.C.s 5.4 million and $\mathrm{Hb} 109 \%$, and in the later, secondary anaemia of the order of Hb $66 \%$ and R.B.C.s $3 \cdot 3$ million. Two barium meals and two barium enemas had been reported normal elsewhere; Professor A. S. Johnstone carried out a barium enema examination in September, and barium meals on the 24 September, 22 October, and 11 November 1958. He found no evidence of peptic ulceration in stomach, duodenum, or jejunum, no sign of fistula formation, and no disease of the colon. The colon was observed to function 'like a large conduit', and some flocculation of the barium was seen in the terminal ileum. Three sigmoidoscopies were negative. Stool examination and culture were repeatedly quite unhelpful, though once Staphylococcus aureus was grown: treatment with erythromycin was rapidly and permanently effective in as much as the stools became negative for staphylococci on culture, but the general course of the illness was not affected. The total plasma proteins and albumin/globulin ratios were normal on five occasions.

The serum electrolytes and plasma $\mathrm{CO}_{2}$-combining power were estimated on 38 occasions: values for serum sodium ranged from 113 to $139 \mathrm{mEq} . / 1$, for serum potassium 2.2 to $3.8 \mathrm{mEq} / 1$, for serum chloride 78 to $100 \mathrm{mEq} / \mathrm{l}$, and for $\mathrm{CO}_{2}$-combining power 15.5 to $24 \mathrm{mEq}$./1. Serum calcium and phosphorus were estimated weekly, values for the former ranging from 9.5 to 13.0 and for the latter 0.8 to $2.1 \mathrm{mEq} . / 1$ respectively. Red cell potassium on 25 November 1958 and 4 December was 86 and $96 \mathrm{mEq} . / 1$. The alkaline phosphatase values at approximately weekly intervals were 45,47 , $52,20,7,21$, and 18 units.

Certain other investigations were carried out.

1 Faecal fat excretion On 6 October 1958, output, $7 \%$, containing $6 \%$ split, $1 \%$ neutral, fat; on 14 October, intake $150 \mathrm{~g}$. over 72 hours and output $25 \mathrm{~g}$. a day.

2 Hydroxyindole acetic acid excretion On 30 October and 23 November, nil.

3 17-Ketosteroid excretion $4.8 \mathrm{mg}$. in 24 hours.

4 Urinary calcium excretion on normal ward diet $310 \mathrm{mg}$. (volume $=830 \mathrm{ml}$.).

5 Urinary potassium excretion On 27 November, $39 \mathrm{mEq} . / 1$; on 1 December, $7.9 \mathrm{mEq} . / 1$.

6 Urinary chloride excretion On 27 November, $58 \mathrm{mEq}$. $/ 1$; on 1 December, $21.4 \mathrm{mEq}$. $/ 1$.

7 Tests for arsenic, antimony, mercury, copper, lead, zinc, and thallium poisoning were negative.

8 An E.C.G. on 20 November showed changes 


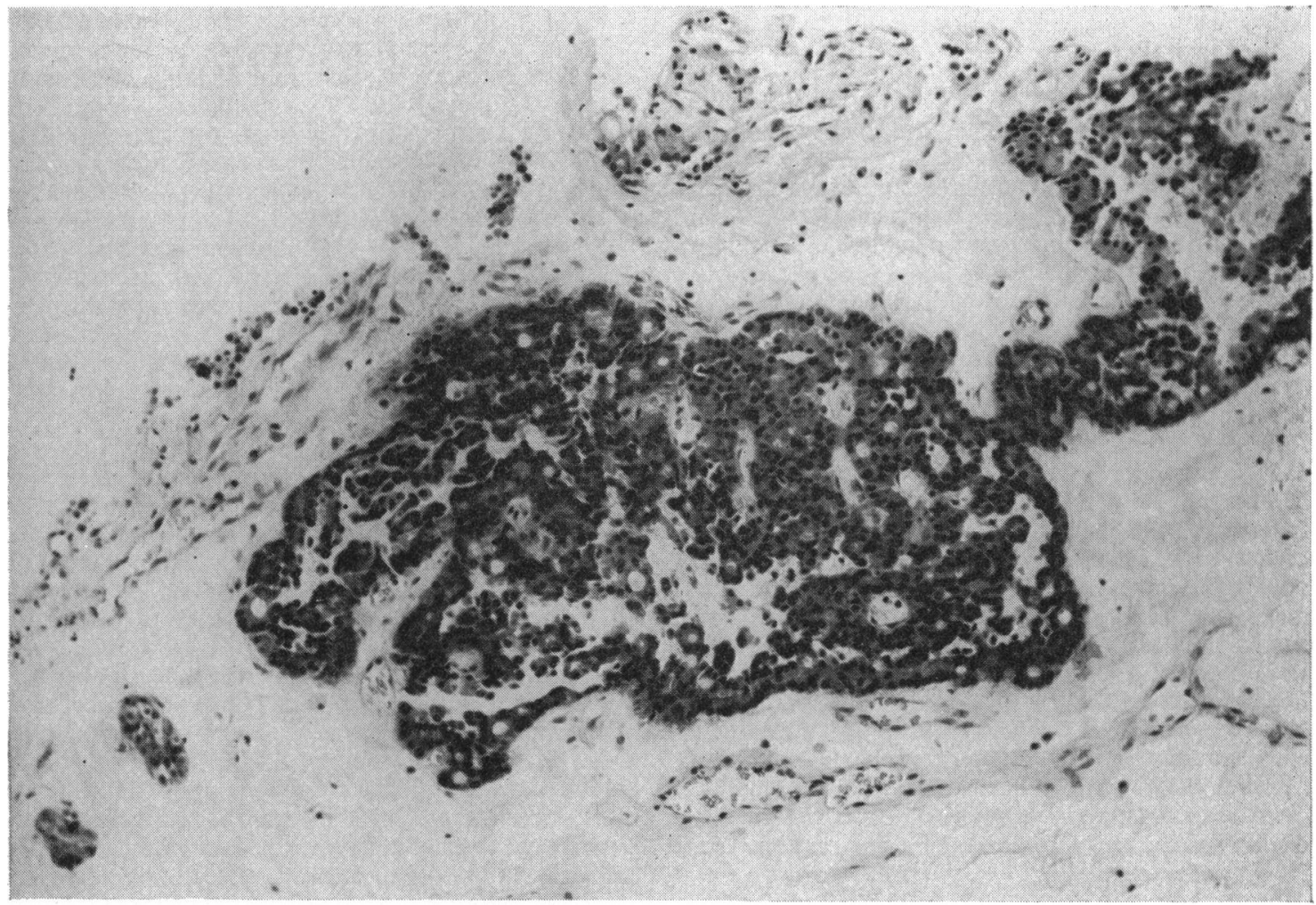

FIG. 1. Tumour cells forming papillary processes, islets, and strands in a partly hyaline stroma. The tumour cells are deeply stained with regular nuclei; the staining reaction of the intracellular granules suggests that the cells are of alpha type (haematoxylin and eosin $\times 300$ ).

consistent with hypokalaemia, which had disappeared on 29 November.

9 On 18 October carmine appeared in the stools six hours after a capsule had been given orally.

TREATMENT The diabetes was always easily controlled by a 12 black and eight red line diet, and some 20 units of Lente insulin daily. It was noted that whenever metabolic control improved the number of daily motions fell, though the total volume remained unchanged.

The persistent loss of fluid, sodium, and potassium was corrected by daily oral or parenteral replacement, regularly reaching a maximum of 5 litres and as much as $6 \mathrm{~g}$. of $\mathrm{KCl}$ or $\mathrm{KHCO}_{3}$. Despite this it was only with difficulty that hypokalaemia and dehydration could be avoided. Symptomatic treatment of the diarrhoea with a gluten-free diet, salazopyrine, and antispasmodics such as Probanthine, was completely ineffective. Prednisolone, $10 \mathrm{mg}$., t.d.s., and later cortisone, $50 \mathrm{mg}$., b.d. increasing to $50 \mathrm{mg}$., six hourly, produced no appreciable diminution in the volume of faeces. In the course of her steroid therapy, she had a small haematemesis on the 5 th and 11th November, the cause being uncertain. No transfusion was needed.
On 5 December her condition had improved sufficiently to allow Mr. A. J. C. Latchmore to carry out a longawaited laparotomy. The only abnormality was a large and obviously malignant growth involving the body and tail of the pancreas; the growth was extremely soft and vascular, and inoperable. There was no evidence of peptic ulceration. A biopsy was taken, and Dr. T. W. Sutherland reported as follows:-

'The biopsy material was stained by haematoxylineosin, phosphotungsic acid haematoxylin, Masson's trichrome stain, and Gomori's chrome-alum haematoxylin. Microscopically columnar and polyhedral epithelial cells form slender strands intermingled with densely hyaline stroma. In some parts the appearances suggest an adenopapillary pattern. Gomori's stain reveals red granules in most of the cells. The findings indicate that this is an adenocarcinoma (Fig. 1) of low-grade malignancy arising in the alpha or delta cells of the Islets of Langerhans'.

\section{DISCUSSION}

Verner and Morrison (1958) noticed particularly the refractory watery diarrhoea in their two patients, 
and were able to collect from the literature seven further patients. In five of these the diarrhoea preceded the symptoms of peptic ulcer by many years, a point noted originally by Zollinger and Ellison (1955), later by Donaldson, vom Eigen, and Dwight (1957), Maynard and Point (1958), Summerskill (1959), and Rawson et al. (1960). The association of steatorrhoea with the Zollinger-Ellison syndrome has been recorded by Maynard and Point (1958), Summerskill (1959), and Rawson et al. (1960). The most acceptable explanation is incomplete neutralization of the large amount of $\mathrm{HCl}$ by pancreatic bicarbonate in the small bowel, the low $p \mathrm{H}$ impairing emulsification and lipolysis.

We suggest that non-insulin-secreting islet cell tumours of the pancreas may be responsible for more than one clinical syndrome. It is clear that profuse intractable watery diarrhoea, hypokalaemia, and hyponatraemia are associated with such pancreatic islet cell tumours, that peptic ulceration may either never develop or that many years may elapse before it finally appears. Table I summarizes 11 case histories, 10 previously recorded and the present one. There seems no doubt that clinicians generally are not fully aware of the association of intractable diarrhoea and islet cell tumours of the pancreas: few examples so far have been recorded.

Only four of the 10 patients in Table I developed peptic ulceration, and in each it had been preceded by a long period of diarrhoea; in one it was terminal. This is very different from the Zollinger-Ellison syndrome, as generally defined, in which peptic ulceration and gastric hypersecretion appear early and are the dominant features. The absence of peptic ulceration in seven, and its late appearance in four, of the patients in Table I, certainly suggest that excessive acid secretion was not the prime cause in these 11 patients. It is true that in only a few case reports has the degree of gastric hypersecretion been measured (Zollinger and Ellison, 1955; Donaldson et al., 1957; Maynard and Point, 1958; Summerskill, 1959; Rawson et al., 1960). A further difficulty is the absence of precise analysis of the faecal discharge; we have been able to discover no report of the electrolytic composition of the faeces, and only in one patient (Rawson et al., 1960) has the faecal volume been measured. On the other hand removal of the tumour in one patient (Brown, Neville, and Hazard, 1950) relieved the diarrhoea. Improvement occurred in Pender's (1959) patient after removal of a pancreatic islet cell tumour, but the most successful result is that described by Rawson et al. (1960) in whose patient removal of the tumour produced complete relief of symptoms and reduced the excessive secretion of acid by the stomach.
The mechanism of the severe faecal loss, which in our patient varied from 1,750 to $6,900 \mathrm{ml}$. daily, must clearly be caused in one of two ways; failure of the absorptive mechanism of the gastrointestinal tract, or increased output of fluid and electrolytes by the gastrointestinal tract. Since a terminal ileostomy normally discharges less than 1 litre of fluid daily which is isotonic with plasma (Smiddy, Smith, Gregory, and Goligher, 1960), it appears most likely that the mechanism involved is oversecretion and hurry. This hypothesis is substantiated by two further facts: first, in five of the 11 patients fat balance studies were made; one had steatorrhoea, but in four normal or near-normal values of faecal fat excretion were found, thus suggesting that the absorptive capacity of the small bowel was essentially normal; secondly, though cortisone normally lowers the fluid output of the small bowel as a result of increased absorption of water and sodium (Smiddy et al., 1960), in our patient $200 \mathrm{mg}$. of cortisone daily produced no diminution in the faecal loss. The possibility also arose that this patient was suffering from hypercatabolic hypoproteinaemia, in which condition diarrhoea has occasionally been reported (Schwartz and Jarnum, 1959), but oedema was never observed and the serum protein levels remained within normal limits throughout.

It is unfortunate that the histological studies of all the tumours so far reported are of little help, because the methods used failed to identify the various islet cell types (Gomori, 1941). Even in the patient described by Rawson et al. (1960) the results were equivocal despite the most modern techniques. The most that can be said from all the reports, including our own, is that the islet cell tumours are not of the insulin-secreting B cell type. Our patient appears to be alone in having proven diabetes in addition.

Solitary tumours were present in nine, and multiple adenomata in two, patients (Table I); five were benign, four malignant, and in two patients the nature of the tissue is not stated. Lymph node metastases were present in one. The proportion of malignant tumours in these 11 patients is much lower than Ellison's (1956) series of 24, of which 19 were malignant. The rate of growth varies considerably; the tumours may remain small, and in three patients were not found at laparotomy. Where excision has been successful, the clinical results appear so far to be good (Brown et al., 1950; Rawson et al., 1960).

The clinical picture of the 11 patients set out in Table I differs significantly from that described by Zollinger and Ellison in four main respects; profuse intractable watery diarrhoea is present for several years; hypokalaemia develops concurrently, and is the commonest mode of death (six of 11 patients); 
TABLE I

CLINICAL SUMMARY OF 11 CASES

\begin{tabular}{|c|c|c|c|c|c|c|c|c|c|c|c|c|c|c|}
\hline & Author & $\operatorname{Sex}$ & Age & $\begin{array}{l}\text { Presenting } \\
\text { Symptoms }\end{array}$ & $\begin{array}{l}\text { Dura- } \\
\text { ation of } \\
\text { Bowel } \\
\text { Symptoms }\end{array}$ & $\begin{array}{l}\text { Previous } \\
\text { Operation } \\
n s\end{array}$ & $\begin{array}{l}\text { Hypokal- } \\
\text { aemia }\end{array}$ & $\begin{array}{l}\text { Peptic } \\
\text { Ulceration }\end{array}$ & $\begin{array}{l}\text { Fat } \\
\text { Absorption }\end{array}$ & Laparotomy & $\begin{array}{l}\text { Cause of } \\
\text { Death }\end{array}$ & Necropsy & Cell Type & 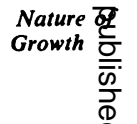 \\
\hline 1 & $\begin{array}{l}\text { Zollinger } \\
\text { and Ellison } \\
\text { (1955) }\end{array}$ & F 3 & 36 & $\begin{array}{l}\text { Diarrhoea, } 8 \\
\text { loss of weight }\end{array}$ & $8 \mathrm{yr}$. & No & $\begin{array}{l}\text { Suspected } \\
\text { on clinical a } \\
\text { history given }\end{array}$ & $\begin{array}{l}\text { Developed } \\
\text { after } 5 \text { yr. } \\
\end{array}$ & $\begin{array}{l}\text { Not } \\
\text { investi- } \\
\text { gated }\end{array}$ & $\begin{array}{l}\text { Jejunal } \\
\text { ulcer }\end{array}$ & $\begin{array}{l}\text { Duodeno- } \\
\text { oesophago- } \\
\text { cutaneous } \\
\text { fistula }\end{array}$ & $\begin{array}{l}\text { Islet cell } \\
\text { tumour } \\
\text { (small) }\end{array}$ & Unknown & 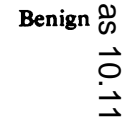 \\
\hline 2 & $\begin{array}{l}\text { Moldawer } \\
\text { et al. } \\
\text { (1954) }\end{array}$ & F 5 & 57 & $\begin{array}{l}\text { Diarrhoea, } \\
\text { loss of weight }\end{array}$ & $4 \mathrm{yr}$. & No & $\begin{array}{l}\text { Renal tubu- A } \\
\text { lar changes } \\
\text { found at } \\
\text { necropsy } \\
\text { suggested } \\
\text { long-standing } \\
\text { hypokalaemia }\end{array}$ & $\begin{array}{l}\text { Absent } \\
\text { g } \\
\text { ia }\end{array}$ & Normal & Not done & $\begin{array}{l}\text { Hypokal- } \\
\text { aemia }\end{array}$ & $\begin{array}{l}\text { Islet cell } \\
\text { tumour } \\
\text { (large) }\end{array}$ & Unknown & 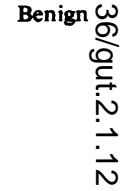 \\
\hline 3 & $\begin{array}{l}\text { Priest and } \\
\text { Alexander } \\
\text { (1957) }\end{array}$ & F 5 & 56 & $\begin{array}{l}\text { Diarrhoea, } \\
\text { loss of weight }\end{array}$ & 6 mth. & $\begin{array}{l}\text { Excision of } \\
\text { pancreatic } \\
\text { neoplasm } \\
5 \text { yr. before } \\
\text { development } \\
\text { of diarrhoea }\end{array}$ & Proved & $\begin{array}{l}\text { Absent but } \\
\text { gastric ulcer } \\
\text { developed } \\
\text { during steroid } \\
\text { therapy }\end{array}$ & $\begin{array}{l}\text { Normal } \\
\text { id }\end{array}$ & Negative & $\begin{array}{l}\text { Hypokal- } \\
\text { aemia }\end{array}$ & $\begin{array}{l}\text { Islet cell } \\
\text { tumours } \\
\text { (small) }\end{array}$ & Unknown & 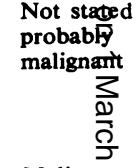 \\
\hline 4 & $\begin{array}{l}\text { Donaldson } \\
\text { et al. } \\
\text { (1957) }\end{array}$ & M 3 & 35 & $\begin{array}{l}\text { Diarrhoea, } 2 \\
\text { tetany, hypo- } \\
\text { chloraemic } \\
\text { alkalosis }\end{array}$ & $2 \mathrm{yr}$. & No & Proved & $\begin{array}{l}\text { Perforated } \\
\text { jejunal ulcer }\end{array}$ & Normal & $\begin{array}{l}\text { Perforated } \\
\text { jejunal ulcer } \\
\text { with } \\
\text { peritonitis }\end{array}$ & $\begin{array}{l}\text { Hypokal- } \\
\text { aemia }+ \\
\text { peritonitis }\end{array}$ & $\begin{array}{l}4 \text { peptic } \\
\text { ulcers, } 2 \\
\text { islet cell } \\
\text { tumours }\end{array}$ & Unknown & 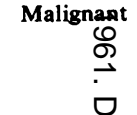 \\
\hline 5 & $\begin{array}{l}\text { Forty and } \\
\text { Barrett } \\
\text { (1952) }\end{array}$ & F 5 & 55 & $\begin{array}{l}\text { Diarrhoea, } \\
\text { loss of } \\
\text { weight, } \\
\text { recurrent } \\
\text { epigastric } \\
\text { pain }\end{array}$ & $3 \mathrm{yr}$. & No & $\begin{array}{l}\text { Not in- } \\
\text { vestigated }\end{array}$ & $\begin{array}{l}\text { Associated } \\
\text { ulcer 3rd } \\
\text { part of } \\
\text { duodenum }\end{array}$ & $\begin{array}{l}\text { Not in- } \\
\text { vestigated }\end{array}$ & $\begin{array}{l}\text { Duodenal } \\
\text { ulcer 3rd } \\
\text { part }\end{array}$ & $\begin{array}{l}\text { Perforation } \\
\text { of recurrent } \\
\text { ulcer post- } \\
\text { operatively }\end{array}$ & $\begin{array}{l}2 \text { islet cell } \\
\text { tumours, } \\
\text { ulceration } \\
\text { of jejunum } \\
\text { opposite } \\
\text { gastrojejunal } \\
\text { stoma }\end{array}$ & $\begin{array}{l}\text { Unknown } \\
\text { I }\end{array}$ & 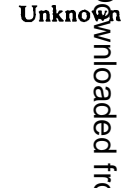 \\
\hline 6 & $\begin{array}{l}\text { Brown } \\
\text { et al. } \\
(1950)\end{array}$ & F 7 & 74 & $\begin{array}{l}\text { Diarrhoea, } \\
\text { loss of weight }\end{array}$ & $4 \mathrm{mth}$. & No & $\begin{array}{l}\text { Not in- } \\
\text { vestigated }\end{array}$ & Absent & $\begin{array}{l}\text { Not in- } \\
\text { vestigated }\end{array}$ & $\begin{array}{l}\text { Tumour of } \\
\text { pancreas }\end{array}$ & $\begin{array}{l}\text { Survived; } \\
\text { after re- } \\
\text { section of } \\
\text { pancreas, } \\
\text { diarrhoea } \\
\text { subsided }\end{array}$ & $\begin{array}{l}\text { Islet cell } \\
\text { tumour } \\
\text { (large) }\end{array}$ & $a \cdot$ cell & 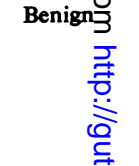 \\
\hline 7 & $\begin{array}{l}\text { Verner } \\
\text { and } \\
\text { Morrison } \\
\text { (1958) }\end{array}$ & M 6 & 67 & $\begin{array}{l}\text { Diarrhoea, } \\
\text { loss of weight }\end{array}$ & $10 \mathrm{mth}$. & No & Proved & Absent & Normal & Not done & $\begin{array}{l}\text { Hypokal- } \\
\text { aemia }\end{array}$ & $\begin{array}{l}\text { Medium } \\
\text { islet cell } \\
\text { tumour, } \\
\text { chromophobe } \\
\text { adenoma of } \\
\text { pituitary }\end{array}$ & Unknown & 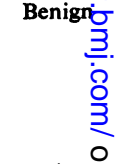 \\
\hline 8 & $\begin{array}{l}\text { Verner } \\
\text { and } \\
\text { Morrison } \\
\text { (1958) }\end{array}$ & M 1 & 19 & $\begin{array}{l}\text { Diarrhoea, } \\
\text { loss of weight }\end{array}$ & 3 yr. & $\begin{array}{l}\text { Exploration } \\
\text { of para- } \\
\text { thyroids }\end{array}$ & Proved & Absent & Normal & Not done & $\begin{array}{l}\text { Hypokal- } \\
\text { demia }\end{array}$ & $\begin{array}{l}\text { Islet cell } \\
\text { tumour } \\
\text { (? size) }\end{array}$ & Not $\beta$ cell & $\begin{array}{r}\text { Benign } \\
\text { D } \\
\text { 을. }\end{array}$ \\
\hline 9 & $\begin{array}{l}\text { Gordon } \\
\text { and } \\
\text { Olivetti } \\
\text { (1947) }\end{array}$ & $\mathbf{M}$ & 26 & $\begin{array}{l}\text { Diarrhoea, } \\
\text { loss of } \\
\text { weight, } \\
\text { acute onset } \\
\text { of upper } \\
\text { abdominal } \\
\text { pain }\end{array}$ & $1 \mathrm{yr}$. & No & $\begin{array}{l}\text { Not proven, } \\
\text { complained } \\
\text { of progres- } \\
\text { sive weak- } \\
\text { ness }\end{array}$ & $\begin{array}{l}\text { Perforated } \\
\text { oesophageal } \\
\text { ulcer after } \\
1 \text { yr. associ- } \\
\text { ated with } \\
3 \text { chronic } \\
\text { duodenal } \\
\text { ulcers }\end{array}$ & $\begin{array}{l}\text { Not in- } \\
\text { vestigated }\end{array}$ & $\begin{array}{l}\text { Jejunostomy } \\
\text { only }\end{array}$ & $\begin{array}{l}\text { Perforated } \\
\text { oesophageal } \\
\text { ulcer }\end{array}$ & $\begin{array}{l}\text { Multiple } \\
\text { pancreatic } \\
\text { tumour } \\
\text { and adrenal } \\
\text { cortical } \\
\text { adenomata }\end{array}$ & Unknown & 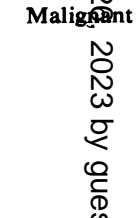 \\
\hline 10 & $\begin{array}{l}\text { Smiddy } \\
\text { and } \\
\text { Telling } \\
\text { (1961) }\end{array}$ & F 4 & 47 & $\begin{array}{l}\text { Diarrhoea, } \\
\text { loss of weight }\end{array}$ & $13 \mathrm{mth}$. & No & Proved & $\begin{array}{l}\text { No ulcer at } \\
\text { operation, } \\
\text { haematemesis } \\
\text { during } \\
\text { steroid } \\
\text { therapy }\end{array}$ & $\begin{array}{l}\text { Slight } \\
\text { is }\end{array}$ & $\begin{array}{l}\text { Tumour of } \\
\text { pancreas }\end{array}$ & $\begin{array}{l}\text { Hypokal- } \\
\text { aemia }\end{array}$ & Not done & $\delta$ - cells & $\begin{array}{c}\text { Maligmant } \\
\frac{0}{\bar{O}} \\
\frac{\mathbb{D}}{\stackrel{D}{D}} \\
\frac{\cap}{D}\end{array}$ \\
\hline 11 & $\begin{array}{l}1 \text { Maynard } \\
\text { and } \\
\text { Point } \\
(1958)\end{array}$ & $\mathbf{M}$ & 53 & $\begin{array}{l}\text { Diarrhoea, } \\
\text { loss of } \\
\text { weight, } \\
\text { abdominal } \\
\text { pain }\end{array}$ & $4 \mathrm{yr}$. & $\begin{array}{l}\text { None for } \\
\text { relevant } \\
\text { condition, } \\
\text { appendi- } \\
\text { cectomy, } \\
\text { chole- } \\
\text { cystectomy }\end{array}$ & $\begin{array}{l}\text { Not proved, } \\
\text { 'non-tropical } \\
\text { sprue' } \\
\text { diagnosed }\end{array}$ & Absent & $\begin{array}{l}\text { Gross, } \\
\text { diagnosed } \\
\text { as 'non- } \\
\text { tropical } \\
\text { sprue' }\end{array}$ & $\begin{array}{l}\text { Large } \\
\text { tumour of } \\
\text { pancreas, } \\
\text { no ulcera- } \\
\text { ation found } \\
\text { at } 2 \\
\text { laparotomies }\end{array}$ & $\begin{array}{l}\text { Malignant } \\
\text { cachexia } \\
\text { and } \\
\text { vomiting } \\
\text { s }\end{array}$ & $\begin{array}{l}\text { Multiple } \\
\text { terminal } \\
\text { jejunal } \\
\text { ulcers } \\
\text { (one had } \\
\text { perforated) }\end{array}$ & $\begin{array}{l}\text { Carcinoma } \\
\text { of islets of } \\
\text { Langerhans }\end{array}$ & 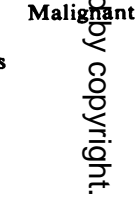 \\
\hline
\end{tabular}


the absence or very late appearance of peptic ulceration; and a lower malignancy rate. Steatorrhoea seems to be associated more with the ZollingerEllison syndrome, but more information is needed before its importance can be accurately assessed.

This leads to the attractive hypothesis that there may be two different types of non-insulin-secreting islet cell tumour of the pancreas: the one may cause gastric oversecretion and peptic ulceration; the other intestinal oversecretion, diarrhoea, and hypokalaemia. How these different reactions are mediated unfortunately remains quite obscure. It is tempting to postulate a hormonal mechanism, but better understanding will only come from further studies of patients with chronic severe diarrhoea or obstinate peptic ulceration, made with particular regard to the possible presence of islet cell tumours.

\section{SUMMARY}

In this paper we have stressed the association between severe watery diarrhoea and islet cell tumours of the pancreas. The clinical picture of this syndrome appears to differ sharply from that of the classical Zollinger and Ellison syndrome in that the clinical course of the disease is prolonged, is dominated by diarrhoea with an attendant severe hypokalaemia, and there is no or very late peptic ulceration. In addition, in the majority of patients there is no steatorrhoea and a lower incidence of malignancy. Comparison, therefore, of these two syndromes suggests that there may be two different types of non-insulin-secreting islet cell tumours but this hypothesis cannot be substantiated in the absence of clear histological methods of differentiating between islet cell types.

We are indebted to Dr. F. M. Parsons, Assistant Director of the M.R.C. Unit, for his help in the control of the electrolyte disturbances, and to the nursing staff for their unfailing care and skill.

\section{REFERENCES}

Brown, C. H., Neville, W. E., and Hazard, J. B. (1950). Islet-cell adenoma, without hypoglycemia, causing duodenal obstruction. Surgery, 27, 616-20.

Donaldson, R. M., vom Eigen, P. R., and Dwight, R. W. (1957). Gastric hypersecretion, peptic ulceration and islet-cell tumor of the pancreas (the Zollinger-Ellison syndrome); report of a case and a review of the literature. New Engl. J. Med., 257, 965-70.

Ellison, E. H. (1956). The ulcerogenic tumor of the pancreas. Surgery, 40, 147-170.

Forty, F., and Barrett, G. M. (1952). Peptic ulceration of the third part of the duodenum, associated with islet-cell tumours of the pancreas. Brit. J. Surg., 40, 60-63.

Gomori, G. (1941). Observations with differential stains on human islets of Langerhans. Amer. J. Path., 17, 395-406.

Gordon, B. S., and Olivetti, R. G. (1947). Carcinoma of the islets of Langerhans; review of the literature and report of two cases. Gastroenterology, 9, 409-424.

Maynard, E. P., and Point, W. W. (1958). Steatorrhea associated with ulcerogenic tumor of the pancreas. Amer. J. Med., 25, 456-459.

Moldawer, P. M., Nardi, G. L., and Raker, J. W. (1954). Concomitance of multiple adenomas of the parathyroids and pancreatic islets with tumor of the pituitary: a syndrome with familial incidence. Amer. J. med. Sci., 228, 190-206.

Pender, B. (1959). Islet-cell tumour of pancreas, associated with peptic ulceration. Lancet, 1, 123-124.

Priest, W. M., and Alexander, M. K. (1957). Islet-cell tumour of the pancreas with peptic ulceration, diarrhoea and hypokalaemia. Ibid, 2, 1145-1147.

Rawson, A. B., England, M. T., Gillam, G. G., French, J. M., and Stammers, F. A. R. (1960). Zollinger-Ellison syndrome with diarrhoea and malabsorption. Ibid, 2, 131-134.

Schwartz, M., and Jarnum, S. (1959). Gastrointestinal protein loss in idiopathic (hypercatabolic) hypoproteinaemia. Ibid, 1, 327-330.

Smiddy, F. G., Smith I. B., Gregory, S. D., and Goligher, J. C. (1960). Faecal loss of fluid, electrolytes, and nitrogen in colitis before and after ileostomy. Ibid, 1, 14-19.

Summerskill, W. H. J. (1959). Malabsorption and jejunal ulceration due to gastric hypersecretion with pancreatic islet-cell hyperplasia. Ibid, 1, 120-123.

Verner, J. V., and Morrison, A. B. (1958). Islet-cell tumor and a syndrome of refractory watery diarrhea and hypokalemia. Amer. J. Med., 25, 374-380.

Zollinger, R. M., and Elliott, D. W. (1959). Pancreatic endocrine function and peptic ulceration. Gastroenterology, 37, 401-411.

- , and Ellison, E. H. (1955). Primary peptic ulcerations of the jejunum associated with islet-cell tumors of the pancreas. Ann. Surg., 142, 709-728. 